\title{
Energy performance of cross-laminated timber panel (X-Lam) buildings: A case study
}

\author{
Francesco Nocera*, Antonio Gagliano, Maurizio Detommaso \\ Department of Civil Engineering and Architecture, University of Catania, V. le Andrea Doria 6, Catania 95125, Italy
}

Corresponding Author Email: fnocera@unict.it

https://doi.org/10.18280/mmep.050307

Received: 15 April 2018

Accepted: 8 June 2018

\author{
Keywords: \\ dynamic energy analysis, X-lam, nZEB, \\ cross laminated timber panel
}

\begin{abstract}
To mitigate the impact of climate change, building designers have to mature novel approaches that enable occupants to remain comfortable in the predictable more warming climate, as well as reduce the environmental footprint and emissions intensity of the building fabric. According to Energy Performance of Buildings Directive (EPBD), energy-efficient buildings represents one of the most accredited ways of reducing energy consumptions in the urbanized area as it requires both high-performance components and technical systems. In the last decades, Cross Laminated Timber Panel (X-Lam) buildings become very popular among the designers of passive and nZEB buildings for their earthquake resistance, excellent air tightness and thermal insulation, which allow achieving remarkable energy savings. In this paper the thermal performance and the indoor comfort of a Cross Laminated Timber Panel (CLT) building, have been evaluated.

This simulation study was carried out adopting two approaches, steady state and dynamic regime, both in Catania and Bolzano two cities that, even belong in the Mediterranean area, are characterized by different climates. Dynamic numerical simulations were performed on a yearly basis through the software Design Builder, both in free-floating conditions and with an air-conditioning (AC) system. Furthermore, the effect of natural ventilation (N.V.) on the thermal behavior of the CLT building was investigated.

The two approaches have provided almost the same energy needs in winter but a significant difference was revealed in summer in both sites. CLT building can lead to indoor overheating of the building in the hottest days of the summer period not only in Catania. Indeed, dynamic simulations in free-floating conditions have highlighted that the $\mathrm{X}$-Lam building fabric suffers even in Bolzano where the operative temperature ranges from $27.2^{\circ} \mathrm{C}$ to $31.8^{\circ} \mathrm{C}$. Moreover, the adoption of N.V. strategies can improve the indoor thermal conditions reducing maximum value of operative temperature around $1.0^{\circ} \mathrm{C}$.
\end{abstract}

\section{INTRODUCTION}

Buildings' energy efficiency improvement has become an international objective for designers and researchers because it has a high potential for reducing Green House Gas emissions [1]. To this aim the concept of Nearly Zero Energy Buildings (nZEB) [2-3] has a role strategic representing a path toward sustainable communities and it is required by the Energy Performance of Building Directive (EPBD) [4].

For satisfying the first requisite of the nZEB, several researches have led to the definition of new architectural shapes, passive design techniques, and innovative technical solutions for both the opaque and the transparent components being suitable for several climate conditions [5-11].

In this context, Cross-Laminated Timber (CLT), also known as "Cross-Lam" or "X-Lam" technology is becoming very popular among the designers of passive and nZEB buildings. The outstanding structural (exceptionally strong relative to its weight) and environmental performance in comparison to concrete or steel have made CLT very popular. The CLT construction system is based on the use of large multi-layer panels made from lumber boards that are glued together, alternating the direction of their fibres for each layer, which improves rigidity, stability, and mechanical properties.
The CLT systems are characterized by a variable thickness, which ranges from 5 to $30 \mathrm{~cm}$, obtained by gluing crossed layers of spruce boards with an average thickness equal to 2 $\mathrm{cm}[12]$.

The cross-laminated nature of the panels implies that they can take up forces in all directions, which allows them to be used as walls, slabs or roofs, in a wide range of applications. Moreover, CLT technology guarantees a simple and fast onsite construction process, providing excellent air tightness and high thermal insulation [13].

The technology based on X-Lam panels enables building structures to avoid thermal bridging (in parapet walls or flat roof solutions), also for multi-storey buildings, consequently the heat losses are significantly reduced. This allows achieving remarkable energy savings in the heating season [14].

Wooden panels have low thermal conductivity, which ranges from 0.10 to $0.18 \mathrm{~W} \mathrm{~m}^{-1} \mathrm{~K}^{-1}$, this allows creating walls with significant thermal resistance and with low thicknesses [15]. In X-LAM constructions, the use of wood, coupled with traditional or innovative thermal insulating materials, increases the thermal resistance of the wall. It is possible to reach values of thermal resistance higher than $\mathrm{R}=3.5 \mathrm{~m}^{2} \mathrm{~K} \mathrm{~W}^{-}$ ${ }^{1}$ (U-value lower than $0.29 \mathrm{~W} \mathrm{~m}^{-2} \mathrm{~K}^{-1}$ ) with thicknesses around $20 \mathrm{~cm}$ [16]. These characteristics allow to achieve a yearly 
energy saving which range from $15 \%$ to $30 \%$ compared to a double brick wall [17].

Moreover, the panels are characterized by high specific heat, even over $1.4 \mathrm{~kJ} \mathrm{~kg}^{-1} \mathrm{~K}^{-1}[17]$.

For these reasons, the technological systems based on CLT have had a widespread diffusion in areas characterized by very cold climates, besides there has been also growing the interest in CLT among designers and architects for its exploiting in temperate climates. Consequently, it would be interesting to analyse thermal and energy performance of CLT buildings in Mediterranean area, particularly in summer period.

To this aim, in this paper, a building characterized by a commercial X-Lam envelope has been modelled and analyzed in Catania and Bolzano, two cities characterized by different climates. The energy assessment of the building envelope was carried out in the steady state by means MasterClima software. Thereby, the energy needs were compared to the corresponding limit values of the Italian regulation.

Moreover, dynamic simulations during a summer week were carried out in order to investigate the thermal behavior of CLT structures as well as the effect of the natural ventilation (N.V.) on thermal comfort.

\section{PROPERTIES OF XLAM PANELS}

Cross-Laminated Panels (X-lam) are composed by crossstacked timber lamellas or wooden planks bonded together by means of a high pressure along the surface $[14,16]$. The lamellas or planks made by coniferous wood or spruce are overlapped so that the grains of each single layer are rotated of $90^{\circ}$ respect to the adjacent ones $[14,16]$.

$\mathrm{X}$-Lam structures are accredited in achieving high quality of comfort due to the positive effect of the mass of wood on the indoor climate and are able to effectively withstand earthquakes or fires as panels exhibit great stability and stiffness in the plane

The properties and performance of cross-laminated timber being a natural renewable product, can vary slightly, but commercial cross-laminated timber systems generally achieve thermal conductivity of $0.13 \mathrm{~W} \mathrm{~m}^{-1} \mathrm{~K}^{-1}$, density of $500 \mathrm{~kg} \mathrm{~m}^{-3}$ (spruce) and compressive strength of $2.7 \mathrm{~N} \mathrm{~mm}$ (perpendicular to grain of boards)

In Table 1 are reported the thermo-physical properties of a cross-laminated timber panel and a Poroton block [18].

The values, reported in table 1, are useful and might help to better understanding the possible difference in thermal dynamic behavior of a CLT structure in comparison to a traditional concrete structure typical of Italian building stock.

Comparing the properties of commercial X-Lam panel and poroton block 700 , it can be noted that the two materials have almost the same density but they have significant difference as concern the specific heat (C) and thermal conductivity (k).

Table 1. Thermo-physical properties of X-lam panels and Poroton block (type 700)

\begin{tabular}{cccc}
\hline Parameters & unit & X-lam & Poroton \\
\hline Thermal conductivity $(\mathrm{k})$ & $\mathrm{W} \mathrm{m}^{-1} \mathrm{~K}^{-1}$ & 0.13 & 0.23 \\
\hline Density $(\rho)$ & $\mathrm{kg} \mathrm{m}^{-3}$ & 500 & 700 \\
\hline Specific heat $(\mathrm{C})$ & $\mathrm{J} \mathrm{kg}^{-1} \mathrm{~K}^{-1}$ & 1,600 & 1,000 \\
\hline Thermal diffusivity " $a$ " & $\left(\mathrm{m}^{2} \mathrm{~s}^{-1}\right)$ & $1.63 \cdot 10^{-7}$ & $\begin{array}{c}3.28 \cdot 10^{-} \\
7\end{array}$ \\
\hline Thermal effusivity " $b$ ” & $\begin{array}{c}\left(\mathrm{W} \mathrm{s}^{1 / 2} \mathrm{~m}^{-2}\right. \\
\left.\mathrm{K}^{-1}\right)\end{array}$ & $3.22 \cdot 10^{2}$ & $4.01 \cdot 10^{2}$ \\
\hline
\end{tabular}

The wooden lamellas are characterized by a thermal capacity higher than Poroton block but their thermal conductivity is lower. Thereby, the thermal diffusivity and effusivity [19] of the cross laminated timber panel are lower than that one of a Poroton block.

\section{METHODOLOGY}

This study was performed considering the building placed at two different climate contexts, Bolzano and Catania.

The aim of this paper is to investigate the heating and cooling aspects of CLT buildings energy performance in the context of the requirements of EPBD for two climatic zone using both dynamic and steady state calculation methodology to obtain more specific information on the behavior of building.

A steady-state simulation tool (Aermec MC11300 [20]) and a dynamic simulation tool (Design Builder) [21] were used. The Steady State method was applied to calculate heating and cooling needs. The dynamic method was specifically used to calculate cooling loads and peak temperatures in naturally ventilated building. Moreover, Design Builder, based on Energy-Plus code [22] was adopted for calculating the energy needs, heating and cooling in presence of AC system.

The building energy needs calculated by means two approaches were compared

In order to evaluate the performance of the building envelope in free-floating conditions, the indoor thermal comfort of the building was evaluated during a week of the summer period $\left(4^{\text {th }}-11^{\text {st }}\right.$ July $)$. This week is quite representative of summer period, because of it is characterized by high external air temperatures and solar radiations in both sites.

In detail, the trend of operative temperature $\left(\mathrm{T}_{\mathrm{op}}\right)$ and Fanger index (PMV) were assessed. In addition, the hourly profiles of outer and inner surface temperature of the wall facades were calculated for assessing the thermal inertia of the external walls. Moreover, the role of nighttime N.V. is also investigated in free-floating conditions.

\subsection{Thermal inertia parameters}

The dynamic behavior of the building opaque elements can be characterized by the periodic thermal transmittance and the time shift, evaluated according to EN ISO 13786:2007 prescriptions [23]. As far as managing solar gain is concerned, the main property of the building envelope to look at is the thermal inertia, and a fairly accepted metric for this property is called periodic thermal transmittance $\mathrm{Y}_{\mathrm{ie}}, \mathrm{Wm}^{-2} \mathrm{~K}^{-1}$. Moreover, the time lag (TL) and the decrement factor (DF) are investigated because they are widely used for characterizing the thermal inertia, heat storage capability of buildings and to evaluate their effect on the indoor wellbeing conditions [2425]. The time lag $(T L)$ is measured by the difference between the times when the maximum outer and inner surface temperatures occur:

$$
T L=\tau_{T_{s i, \max }}-\tau_{T_{s o, \max }}
$$

On the other hand, the decrement factor $(D F)$ is defined as the ratio of the amplitude of the inner surface temperature fluctuations to the amplitude of the outer surface temperature fluctuations: 
$D F=\frac{T_{s i, \text { max }}-T_{\text {si,min }}}{T_{\text {so, } \max }-T_{\text {so,min }}}$

\subsection{Thermal comfort}

The analysis of indoor thermal comfort is carried out by means of Operative temperature $\left(\mathrm{T}_{\mathrm{op}}\right)$ and predicted mean vote index (PMV). The operative temperature is calculated with the following equation:

$T_{o p}=\gamma T_{m r}+(1-\gamma) T_{d r y b u l b}$

where: $\mathrm{T}_{\mathrm{mr}}$, mean radiant temperature; $\mathrm{T}_{\text {drybulb, }}$, mean zone air temperature; $\gamma$, radiant fraction equal to 0.5 .

The thermal wellbeing sensation is evaluated with the approach based on the predicted mean vote index (PMV) that is expressed by P.O. Fanger as:

$P M V=\left(0.303 \cdot e^{-0.026 M}+0.028\right) L$

where: $\mathrm{M}$, metabolic rate; $\mathrm{L}$, thermal load defined as difference between the internal heat production and the heat loss to the actual environment - for a person at comfort skin temperature and evaporation heat loss from sweating to the actual activity level. The PMV index predicts the mean response of a larger group of people according to the ASHRAE thermal sensation scale [26].

\section{CASE STUDY}

The reference building is a timber framed construction. The building is designed using common passive design strategies. It is elongated on the east-west axis with large windows facing south to benefit fully from passive solar heating and daylighting for the main living areas. External shadings are proposed to reduce solar gains due to solar irradiation. Thus, the large opening on the south facade is shaded thanks to horizontal overhang of the roof and vertical side projections of the walls. This allows to partially limiting the solar radiation incoming into the building by the south façade.

While not ideal for sure, having a large and shaded single opening could be very beneficial in the management of the indoor environment without significant reduction of the natural lighting.

In Figure 1 is shown a $3 \mathrm{D}$ view of the building model, a wide glazing placed on the south faced allow to maximize the incoming of natural lighting so that the use of the artificial lighting is reduced.

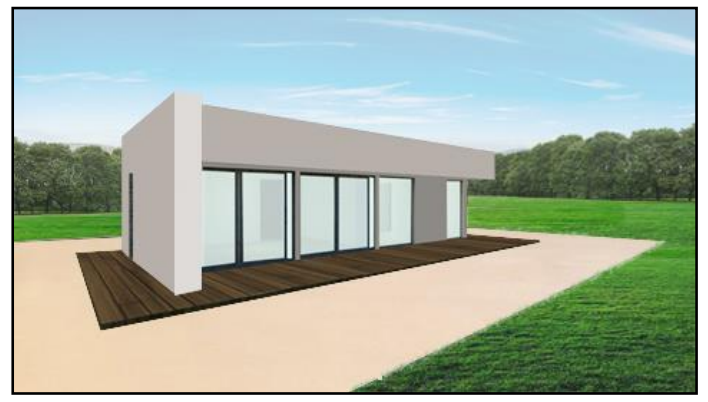

Figure 1. 3D view of the building model
The lighting system operates according to activity typical program of a holiday house. The occupancy density is 0.05 people $\cdot \mathrm{m}^{-2}$ with a power rate of $7 \mathrm{~W} \cdot \mathrm{m}^{-2}$. The occupants are expected to be relaxed with a speed of $0.3 \mathrm{~m} \mathrm{~s}^{-1}$, so metabolic rate of 1.2 Met corresponding to $127 \mathrm{~W}$ person $^{-1}$ was set up. Because the occupants wear summer clothes a clothing thermal insulation of 0.40 clo was considered. The power density of lighting and domestic equipment are $5 \mathrm{~W} \cdot \mathrm{m}^{-2}$ and 3 $\mathrm{W} \cdot \mathrm{m}^{-2}$. The main geometric features of the building are reported in table 2 .

Table 2. Geometric features of the single storey-building

\begin{tabular}{cccc}
\hline Heated gross volume & $\mathbf{V}$ & $\mathbf{1 4 3}$ & $\mathbf{m}^{\mathbf{3}}$ \\
\hline Total opaque surface & $\mathrm{S}_{\mathrm{o}}$ & 160 & $\mathrm{~m}^{2}$ \\
\hline Total transparent surface & $\mathrm{S}_{\mathrm{t}}$ & 21 & $\mathrm{~m}^{2}$ \\
\hline Total external surface & $\mathrm{S}$ & 181 & $\mathrm{~m}^{2}$ \\
\hline Shape factor & $\mathrm{S} / \mathrm{V}$ & 1.26 & $\mathrm{~m}^{-1}$ \\
\hline Transparent/total rate & $\mathrm{S}_{\mathrm{o}} / \mathrm{S}_{\mathrm{t}}$ & 0.12 & - \\
\hline Net floor area & $\mathrm{S}_{\mathrm{u}}$ & 47.6 & $\mathrm{~m}^{2}$ \\
\hline
\end{tabular}

The building envelope is characterized by opaque and transparent components able to realize a high air tightness and provide an air change rate of $0.3 \mathrm{vol} \cdot \mathrm{h}^{-1}$.

\subsection{Building components}

The structural technology adopted for the reference building is based on a commercial module of cross-laminated timber panel (X-Lam). The vertical closures are self-supporting structures characterized by a layer composed by cross-stacked timber lamellas or planks. The insulation layers are placed in the inner and outer side of the walls (Figure 2). The layers and thermo-physical proprieties of the wall are reported in table 3. Overall, the wall has a surface mass $\mathrm{SM}=127 \mathrm{~kg} \mathrm{~m}^{-2}$, a thermal heat capacity $\mathrm{C}=59.82 \mathrm{~kJ} \mathrm{~m}^{-2} \mathrm{~K}^{-1}$ with a $\mathrm{U}$-value $=$ $0.19 \mathrm{~W} \mathrm{~m}^{-2} \mathrm{~K}^{-1}$ and a thermal resistance $\mathrm{R}=5.10 \mathrm{~m}^{2} \mathrm{~K} \mathrm{~W}^{-1}$. This wall has periodic thermal transmittance $\mathrm{Y}_{\mathrm{ie}}=0.022 \mathrm{~W} \mathrm{~m}^{-}$ ${ }^{2} \mathrm{~K}^{-1}$ and $\mathrm{Y}_{\mathrm{ie}}=0.024 \mathrm{~W} \mathrm{~m}^{-2} \mathrm{~K}^{-1}$ in Catania and Bolzano respectively.

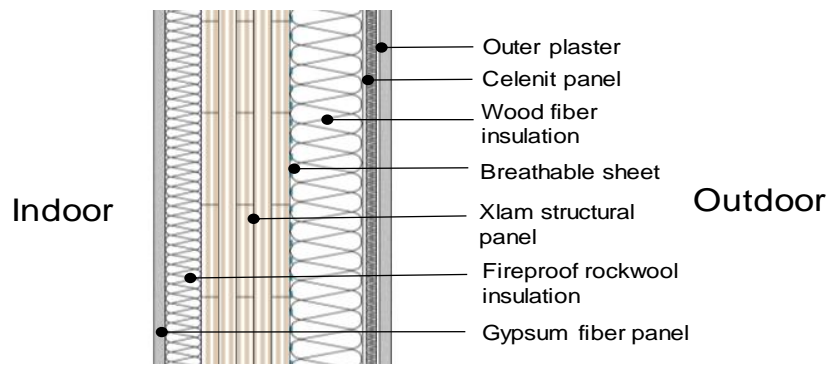

Figure 2. Stratigraphy of the building walls

The Italian Ministerial Decree 26/06/2015 [27] requires that opaque vertical external walls, except walls at North, NorthWest and North-East, must have surface mass not lower than $230 \mathrm{~kg} \cdot \mathrm{m}^{-2}$ or periodic thermal transmittance $\left(\mathrm{Y}_{\mathrm{ie}}\right)$ not higher than $0.10 \mathrm{~W} \cdot \mathrm{m}^{-2} \mathrm{~K}^{-1}$.

In addition, $\mathrm{Y}_{\mathrm{ie}}$ of horizontal or tilted external walls must be lower than $0.18 \mathrm{~W} \cdot \mathrm{m}^{-2} \mathrm{~K}^{-1}$. Consequently, X-Lam structure complies the limit value of periodic thermal transmittance but it is far from the limit value of surface mass. 
Table 3. Stratigraphy and thermal properties of the walls

\begin{tabular}{|c|c|c|c|c|}
\hline Layers & $\mathbf{s}(\mathbf{m})$ & $k\left(W ~ m^{-1} K^{-1}\right)$ & $\rho\left(\mathrm{kg} \mathrm{m}^{-3}\right)$ & $\mathrm{C}\left(\mathrm{J} \mathrm{kg}^{-1} \mathrm{~K}^{-1}\right)$ \\
\hline Outer plaster & 0.02 & 0.80 & 1,600 & 1,000 \\
\hline Celenit panel & 0.015 & 0.038 & 160 & 2,100 \\
\hline Wood fiber insulation & 0.095 & 0.037 & 160 & 2,100 \\
\hline Waterproof and breathable sheet & 0.009 & 0.22 & 500 & 1,000 \\
\hline X-Lam structural panel & 0.10 & 0.13 & 500 & 1,600 \\
\hline Fireproof rock wool insulation & 0.042 & 0.04 & 160 & 1,030 \\
\hline Gypsum fiber panel & 0.013 & 0.18 & 1,300 & 1,000 \\
\hline
\end{tabular}

In addition, the implementation of a green roof and high performance glazing is proposed for achieving a wellinsulated building envelope. The U-value of each proposed building component is reported in table 4 . It also shows the limit $\mathrm{U}$-values $\left(\mathrm{U}_{\mathrm{lim}}\right)$ that the same building components have to comply the Italian regulation [27] in the case of building located in Bolzano (BZ) and Catania (CT) respectively.

Table 4. Opaque envelope and glazing thermal features

\begin{tabular}{cccc}
\hline Type & $\begin{array}{c}\mathbf{U} \\
\left(\mathbf{W} \mathbf{~ m}^{-\mathbf{2}} \mathbf{K}^{-\mathbf{1}}\right)\end{array}$ & $\begin{array}{c}\mathbf{U} \lim -\mathbf{B Z} \\
\left(\mathbf{W} \mathbf{~ m}^{-\mathbf{2}} \mathbf{K}^{-\mathbf{1}}\right)\end{array}$ & $\begin{array}{c}\mathbf{U} \mathbf{l i m}-\mathbf{C} \mathbf{T} \\
\left(\mathbf{W} \mathbf{~ m}^{-\mathbf{2}} \mathbf{K}^{-\mathbf{1}}\right)\end{array}$ \\
\hline External wall & 0.19 & $\leq 0.30$ & $\leq 0.45$ \\
\hline Green roof & 0.25 & $\leq 0.25$ & $\leq 0.38$ \\
\hline Ground floor & 0.16 & $\leq 0.30$ & $\leq 0.46$ \\
\hline Windows & 1.60 & $\leq 1.80$ & $\leq 3.20$ \\
\hline
\end{tabular}

The limit U-values of the opaque and glazing components comply with the regulation limits in both sites. Overall, the building envelope is characterized by a mean overall heat transfer coefficient $\mathrm{H}^{\prime}{ }_{\mathrm{T}}=0.36 \mathrm{~W} \mathrm{~m}^{-2} \mathrm{~K}^{-1}$. Considering a shape factor $\mathrm{S} / \mathrm{V} \geq 0.7 \mathrm{~m}^{-1}$, the reference building has to have $\mathrm{H}^{\prime}{ }_{\mathrm{T}}<$ $0.50 \mathrm{~W} \mathrm{~m}^{-2} \mathrm{~K}^{-1}$ in Bolzano and $\mathrm{H}_{\mathrm{T}}{ }_{\mathrm{T}}<0.58 \mathrm{~W} \mathrm{~m}^{-2} \mathrm{~K}^{-1}$ in Catania according to Italian regulation [27]. Thereby, the building envelope complies the max admissible values of mean global coefficient of thermal transmission in both climate zone.

\subsection{RES, heating and cooling system}

The building is equipped with an air-to-water heat pump (HP) for space heating and cooling.

The HP system has a nominal power of $7 \mathrm{~kW}$ and a coefficient of performance (SCOP) of 3.50, nominal power of $5.29 \mathrm{~kW}$ and $\mathrm{EER}=2.50$ when it operates as chiller. The conditioning system operates with a set-point temperature of $20{ }^{\circ} \mathrm{C}$ during winter and a $26^{\circ} \mathrm{C}$ in summer.

A thermal solar system provides the energy needs for domestic hot water (DHW) and a PV plant of $2.5 \mathrm{~kW}$ peak power (complying with the prescription of the legislative decree no. 28/2011) is also available.

\subsection{Climate features}

The thermal response and energy performance of this building were investigated in two different climates. In Table 5 the main climate data of Bolzano and Catania are reported.

The climate of the two cities are up-loaded in DesignBuilder and Figure 3 depicts the hourly profiles of solar irradiance on the horizontal plane $\left(\mathrm{I}_{\text {hor }}\right)$ and outdoor air temperature $\left(\mathrm{T}_{\mathrm{o}}\right)$ from the $4^{\text {th }}$ to the $11^{\text {th }}$ of July for Catania and Bolzano.

It has to be highlighted that in many days, in Catania, the highest value of outdoor air temperature is lower than ones detected in Bolzano. The solar radiation in Catania is always higher than ones in Bolzano. Catania has a typical
Mediterranean Climate with hot, dry summers and moderately cool, wet winters. In summer, the average outdoor temperature ranges from $20^{\circ} \mathrm{C}$ to $35^{\circ} \mathrm{C}$, with peaks of $40{ }^{\circ} \mathrm{C}$. In winter, the outdoor temperature varies from $5{ }^{\circ} \mathrm{C}$ to $15^{\circ} \mathrm{C}$, while in spring and autumn the climate is mild and the temperatures vary from $10{ }^{\circ} \mathrm{C}$ to $28{ }^{\circ} \mathrm{C}$. Bolzano is characterized by a cold climate with mild summers and cold winters. In summer, the average outdoor temperature ranges from $16^{\circ} \mathrm{C}$ to $30^{\circ} \mathrm{C}$. In winter, the outdoor temperature generally varies from $-5^{\circ} \mathrm{C}$ to $10{ }^{\circ} \mathrm{C}$ whereas in spring and autumn the climate is mild and the outdoor temperature fluctuates from $10{ }^{\circ} \mathrm{C}$ to $20^{\circ} \mathrm{C}$.

Table 5. Geography and climate data

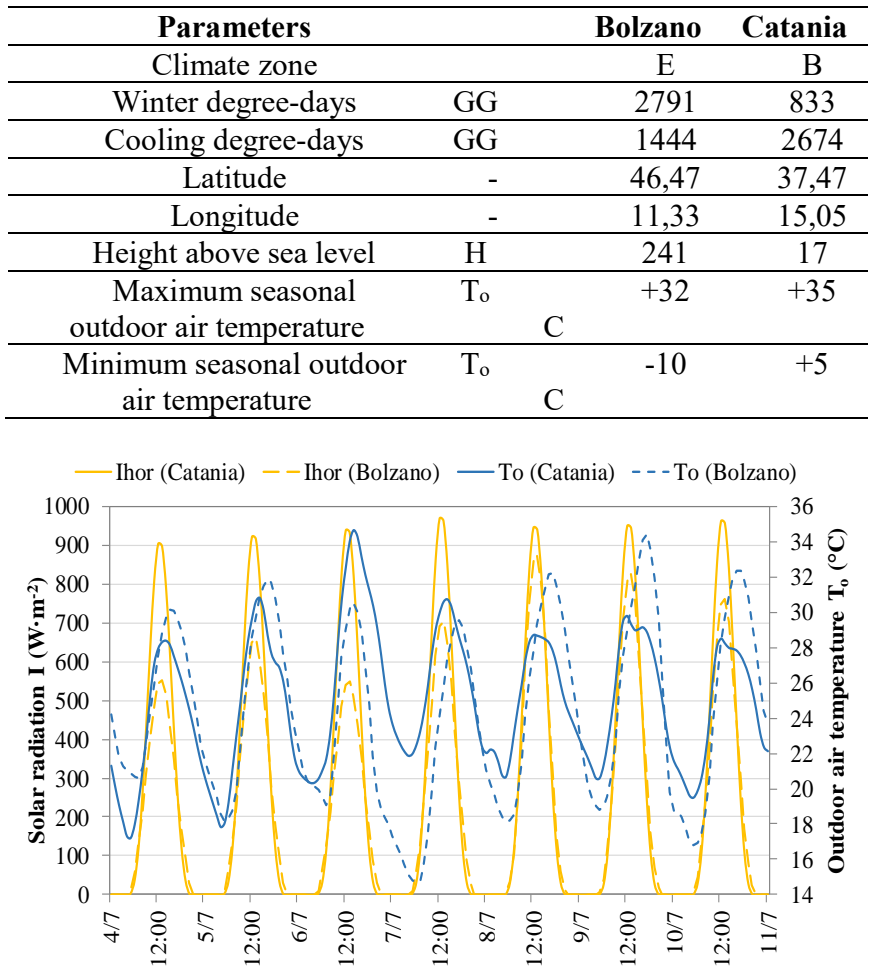

Figure 3. Profiles of solar radiation $\left(\mathrm{I}_{\text {hor }}\right)$ and outdoor air temperature $\left(\mathrm{T}_{\mathrm{o}}\right)$ form $4^{\text {th }}$ July to $11^{\text {th }}$ July

\section{RESULTS AND DISCUSSION}

\subsection{Energy needs for heating and cooling}

The thermal energy needs, expressed in $\mathrm{kWh}$ per unit surface per year, $\left(\mathrm{PE}_{\mathrm{H}, \mathrm{nd}}\right)$ and $\left(\mathrm{PE}_{\mathrm{C}, \mathrm{nd}}\right)$ were compared with the limit values of the reference building in Bolzano and Catania respectively. In Table 6 , the building energy demand for heating and cooling calculated in steady state are shown. It can be noted that the building envelope has a good performance 
during the heating period. The limits for heating $\left(\mathrm{PE}_{\mathrm{H}, \mathrm{nd}}\right)$ are met in both sites. This result highlights that the CLT construction system is useful for guaranteeing the achievement of high building energy performances. Also, in Catania, this building configuration widely satisfies the limit values, in fact, $\mathrm{PE}_{\mathrm{H}, \mathrm{nd}}=6.78 \mathrm{kWh} \mathrm{m}^{-2} \mathrm{y}^{-1}$ that is about $1 / 4$ of the $\mathrm{PE}$,nd,limit.

Table 6. Energy demand for heating and cooling of the building in steady state conditions

\begin{tabular}{cccc}
\hline & & Bolzano & Catania \\
\hline Heating & period & $15^{\text {th }}$ Oct- $15^{\text {st }} \mathrm{Apr}$ & $1^{\text {th }}$ Dic-31 $1^{\text {st }}$ Mar \\
\hline PE $_{H, \text { nd }}$ & $\mathrm{kWh} \mathrm{m}^{-2} \mathrm{y}^{-1}$ & 48.09 & 6.78 \\
\hline PEH,nd,limit & $\mathrm{kWh} \mathrm{m}^{-2} \mathrm{y}^{-1}$ & 61.52 & 38.64 \\
\hline Cooling & period & $15^{\text {th }} \mathrm{Apr}-15^{\text {st }}$ Oct & $1^{\text {th }} \mathrm{Apr}-30^{\text {st }}$ Nov \\
\hline PE $_{\mathrm{C}, \text { nd }}$ & $\mathrm{kWhm}^{-2} \mathrm{y}^{-1}$ & 41.44 & 79.96 \\
\hline PEC,nd,limit & $\mathrm{kWh} \mathrm{m}^{-2}$ & 28.24 & 54.15 \\
\hline
\end{tabular}

Table 7. Energy demand for heating and cooling of building in dynamic thermal behavior

\begin{tabular}{|c|c|c|c|}
\hline & & Bolzano & Catania \\
\hline Heating & period & $15^{\text {th }}$ Oct- $15^{\text {st }} \mathrm{Apr}$ & $1^{\text {th }}$ Dic-31 $1^{\text {st }}$ Mar \\
\hline $\mathrm{PE}_{\mathrm{H}, \mathrm{nd}}$ & $\mathrm{kWh} \mathrm{m}^{-2} \mathrm{y}^{-1}$ & 51.72 & 5.53 \\
\hline $\mathrm{PE}_{\mathrm{H}, \text { nd,limit }}$ & $\mathrm{kWh} \mathrm{m}^{-2} \mathrm{y}^{-1}$ & 61.52 & 38.64 \\
\hline Cooling & period & $15^{\text {th }} \mathrm{Apr}-15^{\text {st }} \mathrm{Oct}$ & $1^{\text {th }} \mathrm{Apr}-30^{\text {st }}$ Nov \\
\hline $\mathrm{PE}_{\mathrm{C}, \mathrm{nd}}$ & $\mathrm{kWh} \mathrm{m}^{-2} \mathrm{y}^{-1}$ & 13.23 & 29.30 \\
\hline $\mathrm{PE}_{\mathrm{C}, \text { nd,limit }}$ & $\mathrm{kWh} \mathrm{m}^{-2}$ & 28.24 & 54.15 \\
\hline
\end{tabular}

On the contrary, the energy needs for cooling of the building do not comply the limit values of $\mathrm{PE}_{\mathrm{C}, \mathrm{nd}}$ both in Bolzano and Catania. The building is characterized by significant energy demand for space cooling. In particular, $\mathrm{PE}_{\mathrm{C}, \mathrm{nd}}$ is $79.96 \mathrm{~W} \mathrm{~m}^{-2}$ $\mathrm{y}^{-1}$ when the building located is in Catania, that is twice of $\mathrm{PE}_{\mathrm{C}, \text { nd,limit. }}$

In table 7 the energy needs of the building in the heating and cooling period calculated by means of dynamic simulation are reported. It has to be highlighted that the heating energy needs calculated by dynamic simulations are almost the same respect to those calculated in steady state, in both sites. In particular, in Bolzano, $\mathrm{PE}_{\mathrm{H}, \mathrm{nd}}$ is $51.72 \mathrm{kWh} \mathrm{m}^{-2} \mathrm{y}^{-1}$ and $48.09 \mathrm{kWh} \mathrm{m}^{-2} \mathrm{y}^{-1}$ in dynamic behavior and steady state respectively.

Instead, the cooling energy needs are significantly lower than the that one calculated in steady state. This difference might be attributed to the different calculation methodology. In particular, in dynamic simulation it is possible to precisely evaluate the reduction of the energy needs during the period when the outdoor air temperature is lower of the set point temperature of the building. In addition, the results show that a building envelope remarkably thermal isolated involves an increase of cooling demand when the calculations are carryout in steady state.

\subsection{Dynamic thermal behavior}

The outer and inner surface temperature of X-Lam walls were calculated by means simulations carried out in summer period (from the $1^{\text {th }}$ to the $31^{\text {th }}$ of July). The simulations were performed starting the calculation with the same value of indoor air temperature for the two cities. Figure 4 shows the trend of $T_{\text {so }}$ and $T_{\text {si }}$ during period $4^{\text {th }}-11^{\text {st }}$ July of a wall east facing oriented in Bolzano and Catania respectively.

The trend of outer surface temperature varies from a maximum value of $47{ }^{\circ} \mathrm{C}$ to a minimum value to $17{ }^{\circ} \mathrm{C}$ in Catania whereas $\mathrm{T}_{\text {so }}$ ranges from $45^{\circ} \mathrm{C}$ to $15^{\circ} \mathrm{C}$ in Bolzano.

The outer temperature attains its peak value in phase with the maximum daily value of the solar radiation on the east facing, that is to say at 9:00 am. It can be noted that the peak values of $\mathrm{T}_{\mathrm{so}}$ in Catania are significantly higher than ones in Bolzano but they are almost coincident for many days. As regard the inner surface temperature an amplitude of fluctuation of about $2.5^{\circ} \mathrm{C}$ is observed both Bolzano and Catania. A gap of $2.0{ }^{\circ} \mathrm{C}$ between Catania and Bolzano is maintained during this week. In Table 8 are reported the dynamic thermal parameters of an east facing oriented wall of the building for the two localities investigated.

The results show that walls based on cross-laminated timber panels (X-lam) have almost the same thermal behavior in the two climate zone. Indeed, there are not difference in terms of time lag (TL) and decrement factor (DF).

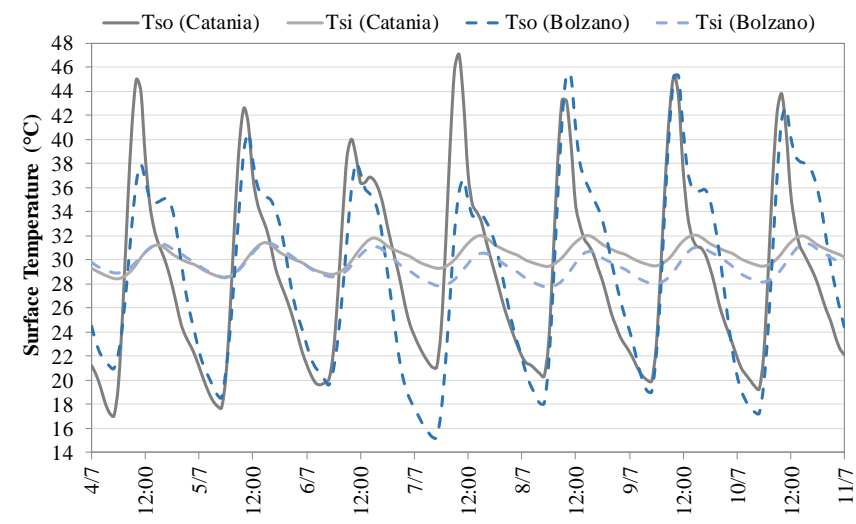

Figure 4. Simulated daily profiles of inner and outer surface temperature of wall facing east

Table 8. Thermal dynamic parameters of an east facing oriented wall of the building in Bolzano and Catania

\begin{tabular}{|c|c|c|c|c|}
\hline & $\mathbf{T}_{\text {so,max }}$ & $\mathbf{T}_{\mathrm{so}, \min }$ & $\mathbf{T}_{\text {si,max }}$ & $\mathbf{T}_{\mathrm{si}, \min }$ TL DF \\
\hline Bol & $45.4^{\circ} \mathrm{C}$ & $15.2^{\circ} \mathrm{C}$ & $31.3^{\circ} \mathrm{C}$ & $27.7^{\circ} \mathrm{C} 4 \mathrm{~h} 0.12$ \\
\hline Tatani & $47.1^{\circ} \mathrm{C}$ & $17.1^{\circ} \mathrm{C}$ & $32.1^{\circ} \mathrm{C}$ & $284^{\circ} \mathrm{C}$ \\
\hline
\end{tabular}

This wall has periodic thermal transmittance $\mathrm{Y}_{\mathrm{ie}}=0.022 \mathrm{~W}$ $\mathrm{m}^{-2} \mathrm{~K}^{-1}$ and $\mathrm{Y}_{\mathrm{ie}}=0.024 \mathrm{~W} \mathrm{~m}^{-2} \mathrm{~K}^{-1}$ in Catania and Bolzano respectively. These values of $\mathrm{Y}_{\text {ie }}$ are close with that one calculated according UNI EN 13786 and, moreover, satisfy the values established by Italian regulation. Nevertheless, this wall is not able to significant attenuate the fluctuation amplitude of 
heat wave as well as to sufficiently delay the peak. Therefore, the heat stored within the wall is released inside the building in the early hours of the afternoon.

\subsection{Assessment of thermal comfort}

The simulated daily profile of operative temperature $\left(\mathrm{T}_{\mathrm{op}}\right)$, during period $4^{\text {th }}-11^{\text {th }}$ of July, are depicted in Figure 5 .

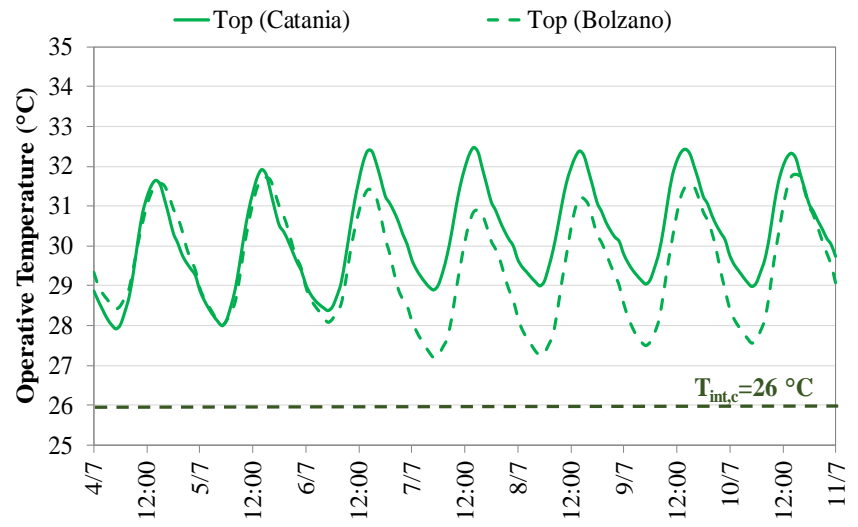

Figure 5. Simulated daily profiles of operative temperature of the building in Catania and Bolzano respectively

It has to be highlighted that in both localities, the operative temperature is always above $26{ }^{\circ} \mathrm{C}$. In Catania, the daily profile shows a wide fluctuation of $\mathrm{T}_{\text {op }}$ that ranges from a minimum of $28{ }^{\circ} \mathrm{C}$ (at 05.00 a.m.) to a maximum of $32.5{ }^{\circ} \mathrm{C}$ (at 15.00 p.m.). In Bolzano, the trend of $\mathrm{T}_{\mathrm{op}}$ ranges from $27.2^{\circ} \mathrm{C}$ (at 05.00 a.m.) to $31.8^{\circ} \mathrm{C}$ (at 15.00 p.m.). It can be noted that $\mathrm{T}_{\mathrm{op}}$ and PMV have almost the same trend. This wall has periodic thermal transmittance $\mathrm{Y}_{\mathrm{ie}}=0.022 \mathrm{~W} \mathrm{~m}^{-2} \mathrm{~K}^{-1}$ and $\mathrm{Y}_{\mathrm{ie}}=0.024 \mathrm{~W} \mathrm{~m}^{-2} \mathrm{~K}^{-1}$ in Catania and Bolzano respectively. In table 9 are reported the maximum and minimum values of $\mathrm{T}_{\mathrm{op}}$ and PMV in Catania and Bolzano respectively.

The analysis of the trends depicted highlights that the same building located in Bolzano, with the same level of thermal insulation, suffers in the hottest hours of summer days. The operative temperature and PMV values confirm that indoor space is not comfortable without a AC plant. As a result, natural ventilation strategies are necessary for achieving better indoor thermal conditions also for a building located in Bolzano.

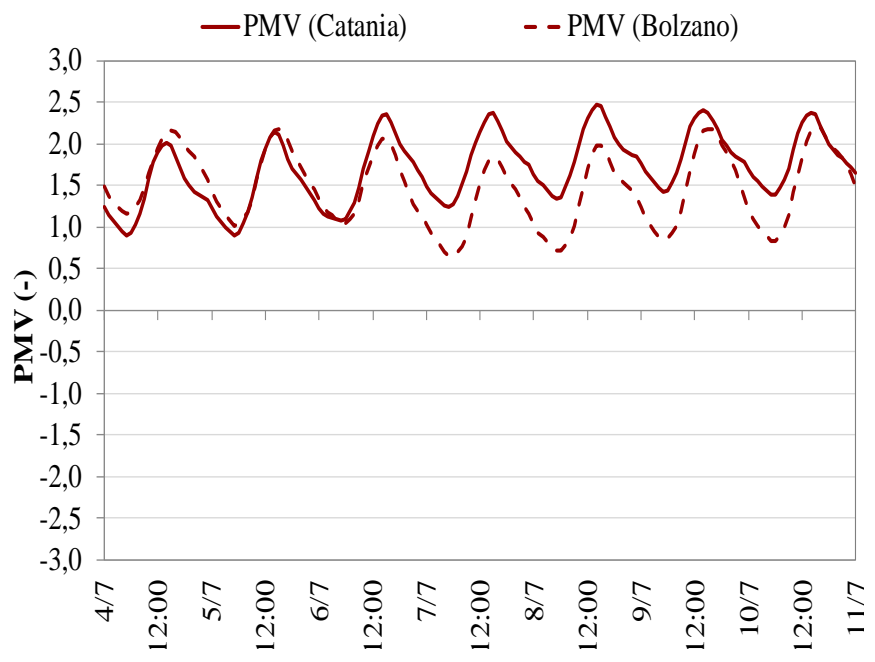

Figure 6. Daily profiles of PMV in Catania and Bolzano
Table 9. Operative temperature and PMV of the building located in Bolzano and Catania

\begin{tabular}{ccccc}
\hline & $\mathbf{T}_{\text {op,max }}$ & $\mathbf{T}_{\text {op,min }}$ & PMV $_{\text {max }}$ & PVM,min $_{\text {m }}$ \\
\hline Bolzano & $31.8^{\circ} \mathrm{C}$ & $27.2^{\circ} \mathrm{C}$ & 2.20 & 0.64 \\
\hline Catania & $32.5^{\circ} \mathrm{C}$ & $27.9^{\circ} \mathrm{C}$ & 2.50 & 0.90 \\
\hline
\end{tabular}

\subsection{Effects of N.V. on the free-running performance}

In this study, the potential effectiveness of N.V. strategies on the indoor thermal conditions are investigated by introducing, in the building, an additional air flow rate from the outdoors between midnight and 6:00 hours, with a constant air change $\mathrm{n}=3.0 \mathrm{ach} \cdot \mathrm{h}^{-1}$. The latter value corresponds to what may be obtained by opening the $33 \%$ of the fenestration surface. The value of $n=3.0 \mathrm{ach} \cdot \mathrm{h}^{-1}$ is a mean value and it was chosen considering that the window is on one side and it could be opened only for a limited time period to improve indoor comfort.

This ventilation rate adds up to the amount of fresh air that is constantly introduced for hygienic purposes $(n=0.3 \mathrm{ach} h$ $1)$.

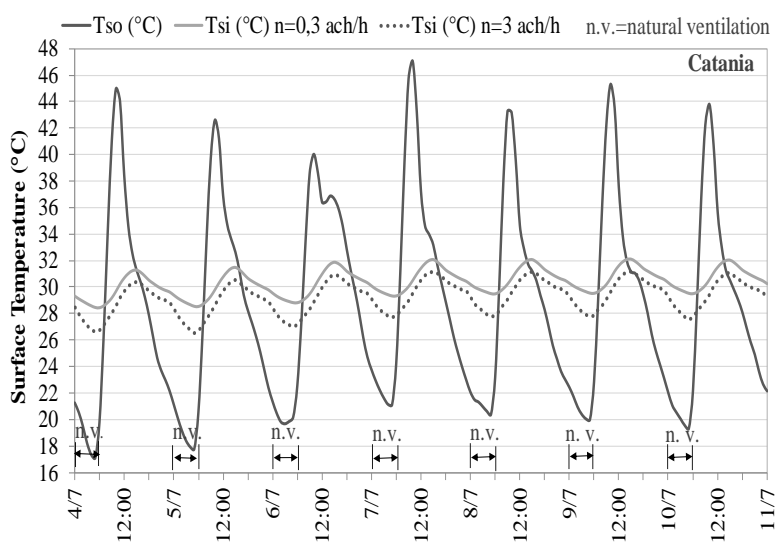

Figure 7. Daily profile of $\mathrm{T}_{\mathrm{si}}$ and $\mathrm{T}_{\mathrm{so}}$ of the east facing oriented wall with and without N.V. in Catania

Figure 7 depicts the profiles of the inner surface temperature of the east facing oriented wall of the building, with and without N.V., in Catania. The profile of outer surface temperature is unchanged compared to the building without N.V. whereas the trend of inner surface temperature is reduced on average of $1.2^{\circ} \mathrm{C}$. $\mathrm{T}_{\mathrm{si}}$ ranges from $26.5^{\circ} \mathrm{C}$ to $31.2^{\circ} \mathrm{C}$. It can be noted that N.V. has a significant effect on the minimum value of inner surface temperature because $T_{\mathrm{si} \text {,min }}$ is averagely reduced by $1.70{ }^{\circ} \mathrm{C}$. Instead, the peak value of $\mathrm{T}_{\mathrm{si}}$ is reduced by $1.0^{\circ} \mathrm{C}$. In Bolzano, the effect of N.V. on the trend of inner surface temperature is almost the same.

The effects of the N.V. on the thermal behavior of east facing oriented wall in Bolzano and Catania are reported in table 10 .

Table 10. Thermal dynamic parameters of an east facing oriented wall of the building with N.V

\begin{tabular}{ccccccc}
\hline & $\mathbf{T}_{\mathbf{s o}, \max }$ & $\mathbf{T}_{\text {so, } \min }$ & $\mathbf{T}_{\text {si,max }}$ & $\mathbf{T}_{\text {si,min }}$ & $\mathbf{T L}$ & $\mathbf{D F}$ \\
\hline Bolzano & $45.4{ }^{\circ} \mathrm{C}$ & $15.2{ }^{\circ} \mathrm{C}$ & $30.6{ }^{\circ} \mathrm{C}$ & $26.0^{\circ} \mathrm{C}$ & $5 \mathrm{~h}$ & 0.16 \\
\hline Catania & $47.1^{\circ} \mathrm{C}$ & $17.1^{\circ} \mathrm{C}$ & $31.2^{\circ} \mathrm{C}$ & $26.5{ }^{\circ} \mathrm{C}$ & $5 \mathrm{~h}$ & 0.15 \\
\hline
\end{tabular}

Figure 8 and 9 depict the effect that N.V. can be provide on the operative temperature and PMV in Catania. 


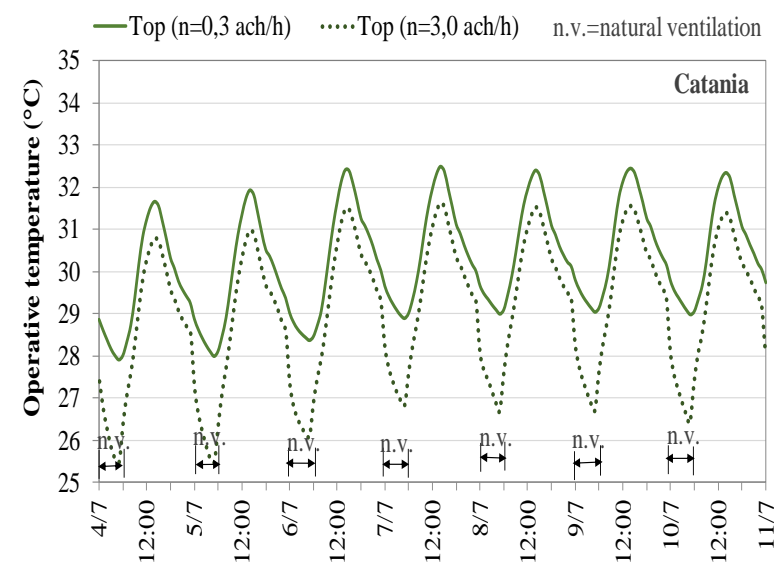

Figure 8. $\mathrm{T}_{\text {op }}$ with and without N.V. in Catania

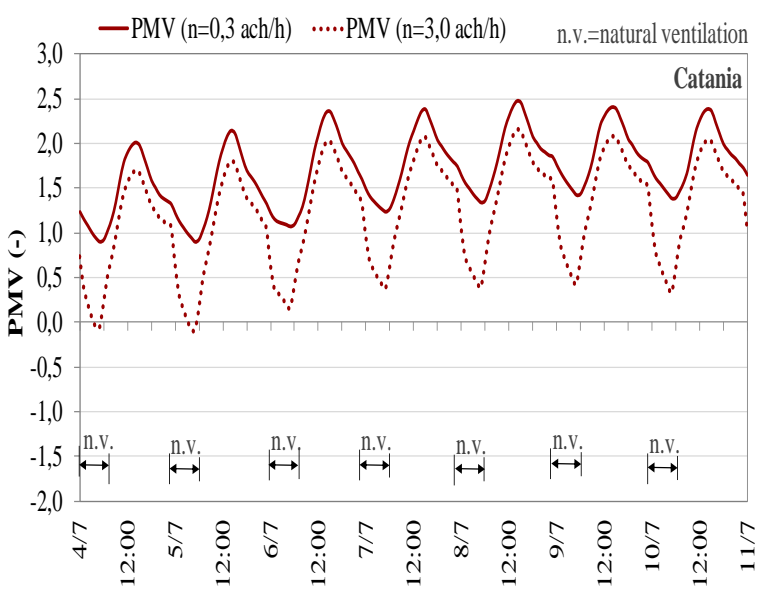

Figure 9. PMV with and without N.V. in Catania

Comparing the results, it can be noted that the operative temperature is decreased on average by $1.0^{\circ} \mathrm{C}$ so that its profile ranges from $25.8^{\circ} \mathrm{C}$ to $31.7^{\circ} \mathrm{C}$. A significant reduction is achieved on the minimum values of operative temperature. In fact, $\mathrm{T}_{\mathrm{op} \text {,min }}$ is decreased of $2.50{ }^{\circ} \mathrm{C}$ whereas the peak value of $\mathrm{T}_{\text {op }}$ is decreased about $1.0^{\circ} \mathrm{C}$. PMV ranges from 0 to 2 thanks to the N.V. The effect of the N.V. on the indoor space of the building located in Bolzano is the same if compared to the results obtained in Catania. Finally, the indoor thermal conditions are significant improved thanks to the contribution of N.V. but the indoor space still suffers in the hottest hours of summer days even in Bolzano. In table 11, $\mathrm{T}_{\text {op }}$ and PMV of the building, with and without natural ventilation, in Bolzano and Catania are shown.

Table 11. $\mathrm{T}_{\text {op }}$ and PMV, with and without N.V

\begin{tabular}{cccccc}
\hline & $\mathbf{T}_{\mathbf{o p}, \max }$ & $\mathbf{T}_{\mathbf{o p}, \min }$ & $\mathbf{P M V}_{\max }$ & $\mathbf{P V M}, \min$ \\
\hline \multirow{3}{*}{ Bolzano } & No ventilation & $31.8^{\circ} \mathrm{C}$ & $27.2^{\circ} \mathrm{C}$ & 2.20 & 0.64 \\
\cline { 2 - 6 } & \multirow{2}{*}{ Ventilation } & $30.9^{\circ}$ & $25.0^{\circ}$ & 1.92 & -0.22 \\
& $\mathrm{C}$ & $\mathrm{C}$ & & \\
\hline \multirow{2}{*}{ Catania } & No ventilation & $32.5^{\circ} \mathrm{C}$ & $27.9^{\circ} \mathrm{C}$ & 2.50 & 0.90 \\
\cline { 2 - 6 } & Ventilation & $31.6^{\circ} \mathrm{C}$ & $25.5^{\circ} \mathrm{C}$ & 2.15 & -0.09 \\
\hline
\end{tabular}

\section{CONCLUSIONS}

This paper investigates, by means dynamic simulations, the energy needs for heating and cooling, thermal inertia and indoor thermal comfort of a building characterized by a commercial X-Lam envelope. This study was carried out considering the building located in Bolzano and Catania.

An energy analysis of the building was performed in steady state and dynamic regime. Building envelope shows moderate heating demand and significant energy needs for space cooling for both sites when the steady state is adopted. In Catania, these results are more pronounced because the energy needs for space heating is about one fifth of the corresponding limit value whereas the cooling demand is about twice the limit value required by the Italian regulation.

The results of dynamic simulation show that the energy needs for space heating of the building are almost the same compared to the steady state. On the contrary, the energy needs for space cooling are significantly lower than cooling demand calculated in steady state. This difference might be due to the different calculation methodologies. In fact, dynamic regime allows to assess the thermal exchange for transmission and infiltration during period when the outdoor air temperature is lower than the indoor set point temperature of the building.

Despite the required limit values by the Italian regulation about periodic thermal transmittance are largely verified, the walls do are not able to significant attenuate and delay the peak of outdoor heat wave.

The analysis in free-running conditions, have showed that the building significantly suffers during representative hot week of summer period. Therefore, this kind of building envelope does not guarantee the comfort and wellbeing thermal of the occupants when the AC system for space cooling is switched off.

Although passive cooling strategy as natural ventilation was implemented the reduction the indoor temperatures was not sufficient to guarantee adequate thermal comfort conditions. Globally, it could be stated that in region where the heating demand is not a critical issue, it would be advisable to adopt only moderate insulation in building envelopes.

\section{REFERENCES}

[1] Pachauri RK, Reisinger A, Pachauri R. (2007). Climate Change 2007: Synthesis Report. Contribution of Working Groups I, II and III to the Fourth Assessment Report of the Intergovernmental Panel on Climate Change. Speculum 77(2): 586-588.

[2] Pospíśila J, Spilaceka M, Bartub M, Martonc D. (2017). Seasonal benefits of intraday heat accumulation in system with air source heat pump for Central Europe climate conditions. Chemical Engineering Transactions 61: 1663-1668. http://dx.doi10.3303/CET1761275

[3] Walmsley T, Klemes J, Walmsley M, Atkins $M$. Verbanov P. (2017). Innovative hybrid heat pump for dryer process integration. Chemical Engineering Transactions 57: 1039-1044. http://dx.doi10.3303/CET1757174

[4] Tsoutsos T, Tournaki S, De Santos CA, Vercellotti R. (2013). Nearly zero energy buildings application in Mediterranean hotels. Energy Procedia 42: 230-238. http://dx.doi.org/10.1016/j.egypro.2013.11.023

[5] Directive 2010/31/EU of the European Parliament and of the Council of 19 May 2010 on the energy performance of buildings.

[6] Wang L, Gwilliam J, Jones P, (2007). Case study of zero energy house design in UK. Energ Buildings 41: 1215- 
1222.

[7] Sun Y. (2015). Sensitivity analysis of macro-parameters in the system design of net zero energy building. Energy Buildings 86: 464-477.

[8] Becchio C, Dabbene P, Fabrizio E, Monetti V, Filippi M. (2015). Cost optimality assessment of a single family house: Building and technical systems solutions for the nZEB target. Energy Build 90: 173-187.

[9] Feng Y. (2004). Thermal design standards for energy efficiency of residential buildings in hot summer/cold winter zones. Energy Building 36: 1309-1312.

[10] Yilmaz Z. (2007). Evaluation of energy efficient design strategies for different climatic zones: Comparison of thermal performance of building in temperate-humid and hot-dry climate. Energy Building 39: 306-316.

[11] Fabrizio E, Corrado V, Filippi M. (2010). A model to design and optimize multi-energy systems in buildings at the design concept stage. Renewable Energy 25: 644 655.

[12] Gagliano A, Detommaso M, Nocera F, Patania F, Aneli S. (2014). The retrofit of existing buildings through the exploitation of the green roofs - A simulation study. Energy Procedia 62: 52-61. http://dx.doi.org/ 10.1016/j.egypro.2014.12.366

[13] Ascione F, Bianco N, De Rossi F, De Masi RF, Vanoli GP. (2016). Concept, design and energy performance of a net zero-energy building in mediterranean climate. Procedia Engineering 169: 26-37. http://dx.doi.org/10.1016/j.proeng.2016.10.004

[14] Lagüela S, Bison P, Peron F, Romagnoni P. (2015). Thermal conductivity measurements on wood materials with transient plane source technique. Thermochimica Acta 600 :

$45-51$ http://dx.doi.org/10.1016/j.tca.2014.11.021

[15] Kosny J, Asiz A, Smith I, Shrestha S, Fallahi A. (2014). A review of high $\mathrm{R}$-value wood framed and composite wood wall technologies using advanced insulation techniques. Energy Buildings 72: 441-456. http://dx.doi.org/10.1016/j.enbuild.2014.01.004

[16] Asdrubali F, Ferracuti B, Lombardi L, Guattari C, Evangelisti L, Grazieschi G. (2017). A review of structural, thermo-physical, acoustical, and environmental properties of wooden materials for building applications. Building Environment 114: $307-$ 332.

[17] Nocera F et al. (2011). Energy analysis of ventilated roof. Smart Innovation, Systems and Technologies 7: 15-23. https://doi.org/ 0.1007/978-3-642-17387-5 2

[18] Ulgen K. (2002). Experimental and theoretical investigation of effects of wall's thermo-physical properties on time lag and decrement factor. Energy Buildings 34: 273-278.

[19] Masterclima.SimulationSoftware http://masterclima.it, accessed on Jan. 17, 2018.

[20] Design Builder. Simulation Software http://designbuilder.co.uk, accessed on Jan. 17, 2018

[21] Energy Plus 6.0, Simulation Software http://energyplus.gov, accessed on Jan. 17, 2018.

[22] EN ISO 13786: 2007- Thermal performance of building components - Dynamic thermal characteristics Calculation methods. 2007, Brussels Belgium.
[23] Gagliano A, Patania F, Nocera F, Galesi A. (2014). Performance assessment of a solar assisted desiccant cooling system. Thermal Science 18(2): 563-576.

[24] Gagliano A, Nocera F, Patania F, Detommaso M, Bruno M. (2015). Evaluation of the performance of a small biomass gasifier and micro-CHP plant for agro-industrial firms. International Journal of Heat and Technology 33(4): 145-154.

[25] World EnergyPlus. (2011). The reference to energy plus calculation, Operative Temperature Control. University of Illinois and University of California, Engineering Reference, pp. 1233-1238.

[26] Italian Republic. (2015). Decree of the Ministry of Economic Development 26/06/2015 Applicazione delle metodologie di calcolo delle prestazioni energetiche e definizione delle prescrizioni e dei requisiti minimi degli edifici. OJ of the Italian Republic.

[27] Italian Republic. (2011). Legislative Decree 3 March 2011, no. 28. Attuazione della direttiva 2009/28/CE sulla promozione dell'uso dell'energia da fonti rinnovabili [...]. OJ of the Italian Republic.

\section{NOMENCLATURE}

b

$\mathrm{C}$

$\mathrm{CP}$

DF

H'

I

$\mathrm{k}$

PE

PMV

$\mathrm{R}$

SM

$\mathrm{T}$

TL

$\mathrm{U}$

$\mathrm{Y}$

\section{Greek symbols}

$\rho$

\section{Subscripts}

C

$\mathrm{H}$

ie

$\max$

$\min$

$\mathrm{mr}$

o

op

si

so

$\mathrm{T}$ thermal diffusivity, $\mathrm{m}^{2} . \mathrm{s}^{-1}$ thermal effusivity, W. $\mathrm{s}^{1 / 2} \cdot \mathrm{m}^{-2} \cdot \mathrm{K}^{-1}$ thermal heat capacity, $\mathrm{kJ} \mathrm{kg}^{-1} \cdot \mathrm{K}^{-1}$ specific heat, $\mathrm{J} \mathrm{kg}^{-1} . \mathrm{K}^{-1}$ decrement factor mean heat transfer coefficient, W. $\mathrm{m}^{-2} \cdot \mathrm{K}^{-1}$ Solar irradiance, W. $\mathrm{m}^{-2}$ thermal conductivity, W. $\mathrm{m}^{-1} \cdot \mathrm{K}^{-1}$ thermal energy needs, $\mathrm{kWh} . \mathrm{m}^{-2} \cdot \mathrm{y}^{-1}$ predicted mean vote thermal resistance, $\mathrm{m}^{2} . \mathrm{K} . \mathrm{W}^{-}$ thickness, $\mathrm{m}$ surface mass, $\mathrm{kg} . \mathrm{m}^{-2}$ temperature, ${ }^{\circ} \mathrm{C}$ time lag, h thermal transmittance, $\mathrm{W} . \mathrm{m}^{-2} \cdot \mathrm{K}^{-1}$ periodic thermal transmittance, $\mathrm{W} \cdot \mathrm{m}^{-2} \cdot \mathrm{K}^{-1}$ density, $\mathrm{kg} \cdot \mathrm{m}^{-3}$

time, $\mathrm{h}$

cooling

heating

internal-external

maximum

minimum

mean radiant temperature

outdoor

operative

inner surface

outer surface

thermal 